УДК 616.89-008.441.13:312.2(497.4)

\title{
J. Sidlo
}

\section{MANAGEMENT OF MONITORING OF DRUG RELATED DEATHS IN SLOVAKIA}

\author{
Institute of Forensic Medicine, School of Medicine, Comenius University, Bratislava, Slovakia
}

\begin{abstract}
Using illicit drugs as well as other psychoactive substances represents a serious health and social problem. Monitoring of drug-related deaths and mortality rates among drug users is one of the essential indicators of the seriousness of the drug-related problem. The obtained data serve as one of the bases for shaping the anti-drug policy and strategy not only at the national but also international level. The aim of the research is to describe the management of monitoring of drug - related deaths and building up the so-called Special Register of drug related deaths in Slovakia and present the results obtained by performing
\end{abstract}

Introduction. Abuse of psychoactive substances, i.e. illicit drugs together with medicaments available on prescription, represents a serious health and social problem. Surveys of deaths related to psychoactive substances are a useful indicator of trends in their abuse in each country [1]. Several studies on illicit drug related deaths in Europe have been published but the data presented are difficult to compare due to the lack of standardized data collection in particular countries. In Slovakia the problem of drug abuse was highlighted in the years following the political changes in 1989, when Slovakia opened up to the world and thereby to the world of drugs [2, 3]. Systematic monitoring of psychoactive substances related deaths for the use of the European Monitoring Centre for Drugs and Drug Addictions (EMCDDA) in Lisbon started in Slovakia in 2005 after its admission to the European Union (EU) in 2004. This monitoring is obligatory for member states of the EU.

The purpose of the study. The purpose of the study is presentation of the experiences obtained by monitoring of drug related deaths in Slovakia since the year 2004 .

Material and methods. The study included all those deceased who died in relation to drug abuse and were submitted to medicolegal autopsy and a toxicological investigation in Slovakia within a seven-year period of the years 2004-2010 at the nine medicolegal workplaces of Healthcare Surveillance Authority (HCSA). The cases were divided into two groups - direct deaths and indirect deaths according to the criteria of EMCDDA.

The data on deaths within the years 2004 throuth 2005 were collected from all workplaces retrospectively. Since 2006 a continuing data collection started via electronic on-line forms on the webpage of the National Monitoring Centre for Drugs ( NMCD), which were filled in by a physician performing the autopsy and this data collection continued up to 2008. Since 2009 the electronic database of the autopsy reports conducted by HCSA for data collecting has been used. an analysis of all the cases reported during the period of years from 2004 to 2010 . The results of the analysis for further management of the collection of the data have shown the necessity to define a network of laboratories, develop the concept of the Slovak forensic toxicology, and introduce standard guidelines for a proper indication of examinations, interpretation of results, and establishment of the diagnosis of psychoactive substances-related deaths.

Key words: drug-related deaths, autopsy, toxicological analysis, monitoring, management.

The population in Slovakia within a monitored period was about 5.4 million, on the average more than 53 thousand people died a year and the number of performed medicolegal autopsies was 39.837.

Results. The criteria matched 757 cases i.e. $1,9 \%$ of all autopsies. There were $39 \%$ of direct deaths and $61 \%$ of indirect deaths. Males comprised $73 \%$ of all cases and females $27 \%$. The age category up to 34 years represented $50 \%$ of cases. The most frequently detected substances were opiates and opioids in direct deaths in $31 \%$ of cases, in indirect deaths - benzodiazepines in $34 \%$.

The rate of lethal cases rate related to overdosing with illicit drugs ranged from 4 to 6 (the mean number 5) per 100,000 population at the age ranging from 15 to 64 years. This fact ranks Slovakia among four countries with the lowest death rate of overdosing with illicit drugs in Europe.

\section{Conclusion}

Reported results fail to determine definite trends in the development of the indicator in Slovakia since the reported mortality rate is relatively low. It deals with the initial attempts of a complex evaluation of the problems from the beginning of building up the so-called Special Register. The key aspect affecting the resulting figures is the fact that unlike in other countries in Slovakia there are registered only those cases in which autopsy and a complex toxicological analysis were performed [2].

Prospects for further research. The results of the analysis for further management of the collection of the data have shown the necessity to define a network of laboratories, develop the concept of the Slovak forensic toxicology, and introduce standard guidelines for a proper indication of examinations, interpretation of results, and the establishment of the diagnosis of psychoactive substances-related deaths. In order to improve the quality of case monitoring it is required to extend indications of screening toxicological examinations for defined risk groups in terms of the death cause, age and history, particularly, in so-called indirect drug-related deaths. For the notifi- 
cation of cases, it is necessary to modernize and improve the effectiveness of the electronic database of autopsy reports conducted by Health Care Surveillance Authority [1].

\section{Literature}

1. Sidlo, J. Quality of the monitoring of drug-related deaths in Slovak republic (in Slovak) / J. Sidlo // Folia Societatis Medicinae Legalis Slovacae. - 2012. - P. 70-81.
2. Sidlo J. Psychoactive substances related to the deaths. Bratislava / J. Sidlo// Medical J. - 2012. - P. 26-29.

3. Sidlo, J. Somatic and fatal consequences of opiates and opioids abuse (in Slovak) / J. Sidlo //Alkoholizmus a drogové závislosti. - 2012. - P. 271-284.

\section{УПРАВЛЕНИЕ МОНИТОРИНГА СМЕРТНОСТИ В РЕЗУЛЬТАТЕ ДЕЙСТВИЯ НАРКОТИЧЕСКИХ ВЕЩЕСТВ В СЛОВАКИИ}

\section{Д. Сидло}

Резюме. Употребление наркотических и других психотропных веществ есть серьезной проблемой здравоохранения. Мониторинг смертности в результате употребления наркотических и психотропных веществ есть основой формирования антинаркотической политики и стратегии не только на национальном, но и на международном уровне. В роботе описано управление мониторинга смертей вследствие употребления наркотиков и создание специального реестра этих смертей в Словакии. Проведен анализ всех случаев, зарегистрированных в период с 2004 по 2010 год.

Ключевые слова: наркотические вещества, токсикологический анализ, мониторинг, управление.

\section{УПРАВЛІННЯ МОНІТОРИНГУ СМЕРТНОСТІ В РЕЗУЛЬТАТІ ДІї НАРКОТИЧНИХ РЕЧОВИН У СЛОВАЧЧИНІ}

\section{Д. Сідло}

Резюме. Вживання наркотичних та інших психотропних речовин $є$ серйозною проблему охорони здоров'я. Моніторинг смертності, пов'язаної з вживанням наркотичних та психотропних речовин, $є$ однією з основ для формування антинаркотичної політики і стратегії не тільки на національному, але й на міжнародному рівні. У роботі описано управління моніторингу, пов'язаних з наркотиками смертей і створення так званого спеціального реєстру, пов'язаних із наркотиками смертей у Словаччині. Проведений аналіз усіх випадків, зареєстрованих у період iз 2004 по 2010 рік.

Ключові слова: наркотичні речовини, токсикологічний аналіз, моніторинг, управління.

Інститут Судової Медицини, Школа Медицини, Університет ім. Коменіуса (Братислава, Словаччина) ВИПАДКИ ІЗ ПРАКТИКИ

Київське обласне бюро судово-медичної експертизи

Резюме. Правильно організована тактика проведення експертизи (дослідження) із залученням необхідних спеціалістів та проведенням усіх необхідних інструментальних та лабораторних досліджень на базі ведучих наукових закладів або багатопрофільних лікарень, взаємодія зі слідчими органами дає можливість комісії експертів об'єктивно та науково-обгрунтовано відповідати на питання, що ставляться на вирішення при розслідувані кримінальних справ із приводу незаконного вилучення органів та тканин людини.

Ключові слова: комісійна експертиза, незаконне вилучення органів. 